\title{
Management Optimization of Saguling Reservoir with Dynamic Programming Bellman and "Du Couloir" Iterative Method
}

\author{
Mariana Marselina $^{1 *}$, Arwin Sabar ${ }^{1}$, Indah R S Salami ${ }^{1}$, and Dyah Marganingrum ${ }^{2}$ \\ ${ }^{1}$ Environmental Engineering Program, Faculty of Civil and Environmental Engineering, ITB \\ ${ }^{2}$ Indonesian Institute of Sciences (LIPI) \\ *Corresponding author (email: mariana.marselina@yahoo.com)
}

\begin{abstract}
The increasingly growth of population and industry sector have lead to an enhanced demand for electrical energy. One of the electricity providers in the area of Java-Madura Bali (Jamali) is Saguling Reservoir. Saguling Reservoir is one of the three reservoirs that stem the flow of Citarum River in advance of to Jatiluhur and Cirata Reservoir. The average electricity production of Saguling Reservoir was 2,334,318.138 MWh/year in the period of 1986-2014. The water intake of Saguling Reservoir is the upstream Citarum Watershed with an area of $2340.88 \mathrm{~km}^{2}$ which also serves as the irrigation, inland fisheries, recreation, and other activities. An effort to improve the function of Saguling Reservoir in producing electrical energy is by optimizing the reservoir management. The optimization of Saguling Reservoir management in this study refers to Government Regulation No. 37/2010 on Dam/Reservoir Article 44 which states that the system of reservoir management consisting of the operation system in dry years, normal years, and wet years. In this research, the determination of the trajectory guideline in Saguling operation was divided in dry, normal and wet years. Trajectory guideline was conducted based on the electricity price of turbine inflow that various in every month. The determination of the trajectory guideline in various electricity price was done by using Program Dynamic Bellman (PD Bellman) and "Du Couloir" iterative method which the objective to optimize the gain from electricity production. and "Du Couloir" iterative method was development of PD Bellman that can calculate the value of gain with a smaller discretization until 0,1 juta $\mathrm{m}^{3}$ effectively where PD Bellman just calculate until 10 million m3. Smaller discretization can give maximum benefit from electricity production and the trajectory guideline will be closer to trajectory actual so optimization of Saguling operation will be achieved.
\end{abstract}

Keywords: Bellman, volume discretization, time discretization, Du Couloir, reservoir optimization.

\begin{abstract}
Abstrak
Peningkatan laju pertumbuhan penduduk dan industri mendorong peningkatan kebutuhan akan energi listrik. Salah satu penyedia kebutuhan enegi listrik di wilayah Jawa Madura Bali (Jamali) adalah Waduk Saguling. Waduk Saguling termasuk dalam tiga waduk series yang membendung aliran Sungai Citarum sebelum Waduk Jatiluhur dan Waduk Cirata. Rata-rata produksi listrik Waduk Saguling dari tahun 1986-2014 adalah 2.334.318,138 MWh/tahun. Asupan air bagi Waduk Saguling adalah Daerah Aliran Sungai (DAS) Citarum Hulu dengan luas 2.340,88 $\mathrm{km}^{2}$ yang juga memiliki fungsi bagi masyarakat untuk memenuhi kebutuhan irigasi, perikanan darat, rekreasi, dan berbagai aktivitas lainnya. Salah satu upaya yang dapat ditempuh untuk meningkatkan fungsi Waduk Saguling sebagai penghasil energi listrik adalah dengan melakukan optimasi pengelolaan waduk. Optimasi pengelolaan Waduk Saguling dalam penelitian ini mengacu pada PP No. 37 Tahun 2010 tentang Bendungan pasal 44 yang menyatakan bahwa pola operasi waduk terdiri atas pola operasi tahun kering, tahun normal, dan tahun basah. Pada penelitian ini, penentuan lintasan pedoman pada operasional Waduk Saguling juga dilakukan pada tahun basah, tahun normal, dan tahun kering. Penentuan lintasan pedoman dilakukan berdasarkan harga satuan unit energi listrik yang dihasilkan dari turbin dimana nilai unit energi listrik tersebut berbeda pada setiap bulannya. Penentuan lintasan pedoman pada penelitian ini dilakukan dengan Program Dinamik Bellman dan Metode Iteratif "Du Couloir" dengan obyektif untuk memaksimalkan nilai gain dari produksi listrik. Metode iteratif "Du Couloir" merupakan pengembangan dari PD Bellman yang dapat menentukan lintasan pedoman hingga diskrtisasi terkecil mencapai 0,1 juta m3 secara efektif dimana PD Bellman hanya mampu menghitung dengan efektif hingga diskritisasi volume 10 juta m3. Semakin kecil diskritisasi yang dilakukan akan memberikan nilai gain dari produksi listrik yang semakin optimum dan pedoman lintasan pedoman yang diperolah akan semakin mendekati kepada lintasan aktual yang terjadi. Hal ini menunjuukkan adanya optimasi dalam pengoperasian Waduk Saguling.
\end{abstract}

Kata kunci: Bellman, diskritisasi volume, diskritisasi waktu, Du Couloir, pengelolaan waduk 


\section{Introduction}

The massive growths of human population and industry sector have led to increasingly demand for electricity by year. In 1993/1994, the consumption of electricity of Java and Bali was 41,347 GWH (Giga Watt Hour) with a peak of 6,821 MW (Mega Watt), meanwhile, in 2003/2004 it reached $162,104 \mathrm{GWH}$ with a peak of 25,700 MW (Nugroho, 1999 in Gunawan, 2005). In 2003, total demand for electricity of Java-Madura-Bali (Jamali) was 69,96 TWH (Tera Watt Hour) and in 17 years (2003-2020) it is estimated that it will increase by $6 \%$ per year which is a slightly lower than the average electricity demand in Indonesia. By 2020, total demand for electricity in Jamali will be as much as 203,19 TWH (Muchlis, 2003).

Saguling Reservoir is one of reservoirs that stems the flow of Citarum River before it is contained by Jatiluhur Reservoir and Cirata Reservoir. Saguling Reservoir is $643 \mathrm{~m}$ above sea level in altitude with a capacity of 1400 MW. The water intake for Saguling Reservoir is Citarum Upstream Watershed with an area of $2340.88 \mathrm{~km}^{2}$. It has several functions for the communities including for irrigation, inland fisheries, recreation, and other activities. Such reservoirs are commonly prone to degradation (Santosa and Mitani, 2015).

The optimization of Saguling Reservoir management in this study referred to Article 44 of PP No. 37/2010 about Reservoir regarding with the system of reservoir management that consists of operational system in the dry years, normal years, and wet years. The determination of trajectory guideline of those years was carried out based on the electricity price for electricity production from turbin which have various values in every month.

Over the past decades, DP Bellman had been used extensively in the optimization of reservoir management. In the discrete form of DP Bellman, storage of each reservoir is discretized into a finite number of levels. By exhaustive enumeration over all possible combinations of discrete levels at each stage for all reservoirs in a system, global optimality can be assured in a discrete sense. However, the well-known "curse of dimensionality" limits the application of DP Bellman to multi-state variable problems, as the state space increases exponentially with an increase in the number of state variables. A variety of DP Bellman development, such as incremental dynamic programming (IDP) [Larson, 1968], dynamic programming successive approximations (DPSA) [Larson, 1970], incremental dynamic programming and successive approximations (IDPSA) [Yeh, 1973] and discrete differential dynamic programming (DDDP) [Chow, 1971] have been proposed to alleviate the dimensionality problem.

In this research, the development of DP Bellman that been used was "Du Couloir" Iterative Method which the concept was found by Thirriot, Arwin, EDF-France, 1991 firstly. Reservoir management with Bellman dynamic programming and "Du Couloir" iterative method is an attempt to gain a higher profit from electricity production of Saguling Reservoir, hence, the optimal management of Saguling Reservoir will be achieved in the future.

\section{Research Methods}

Essential data in this reserarch was discharge inflow from Saguling station. Data was collected from 1986-2013 in every month. Beside that, the other important data was characteristic of Saguling reservoir that will be used as constraints in PD Bellman to determine the trajectory guideline. The characteristic of Saguling reservoir consits of : water level in Saguling reservoir $(623 \mathrm{~m} \mathrm{dpl}-643 \mathrm{~m} \mathrm{dpl}$; maximum volume in Saguling reservoir which is 609 juta $\mathrm{m} 3$; and installed turbine capacity in Saguling reservoir $\left(112 \mathrm{~m}^{3} / \mathrm{s}-224 \mathrm{~m}^{3} / \mathrm{s}\right.$ for 4 turbine) 


\section{Study Location}
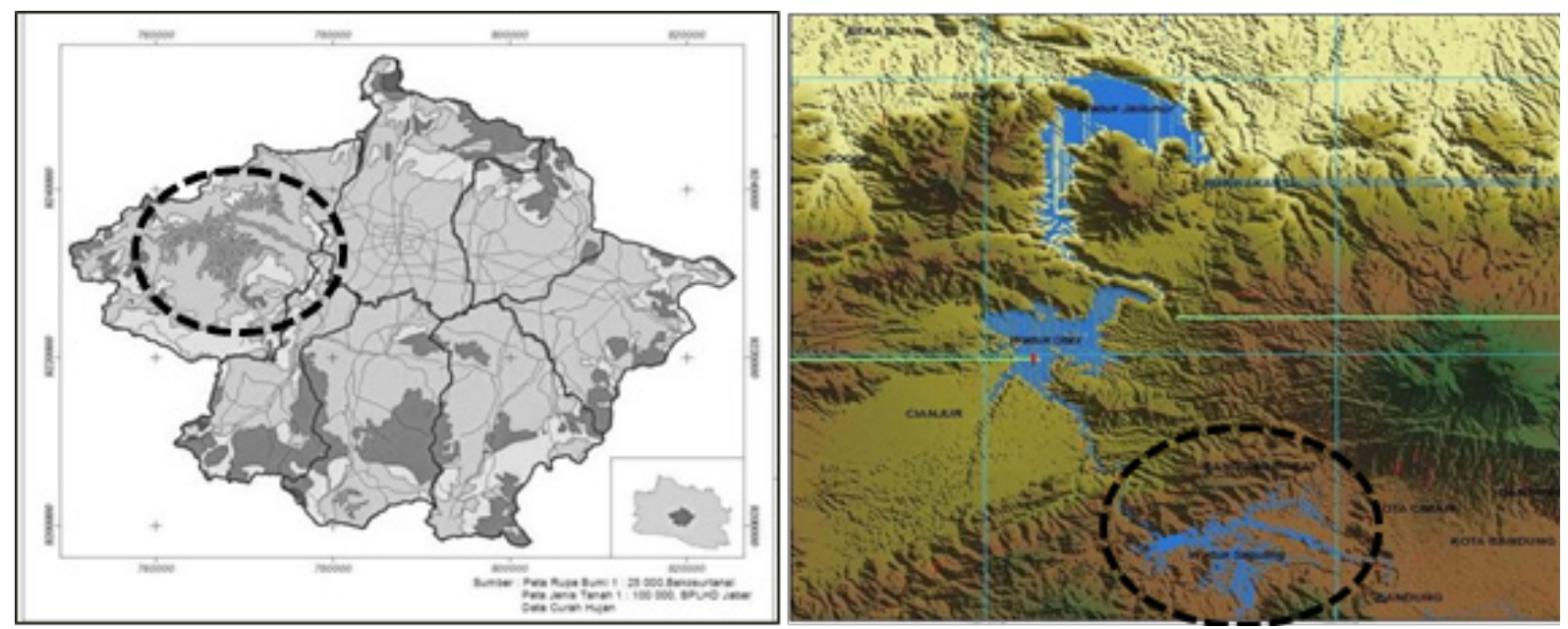

Figure 1. Study Location

This research was conducted in Saguling Reservoir in Upstream Citarum Watershed. Saguling reservoir is a part of kaskade reservoirs in Citarum besides Cirata Reservoir and Jatiluhur resevoir. Coordinat location of Saguling reservoir is 6 $6^{\circ} 56^{\prime} 25^{\prime \prime} \mathrm{S} 107^{\circ} 25^{\prime} 19^{\prime \prime} \mathrm{E}$.

\section{Flowchart of Metodology}

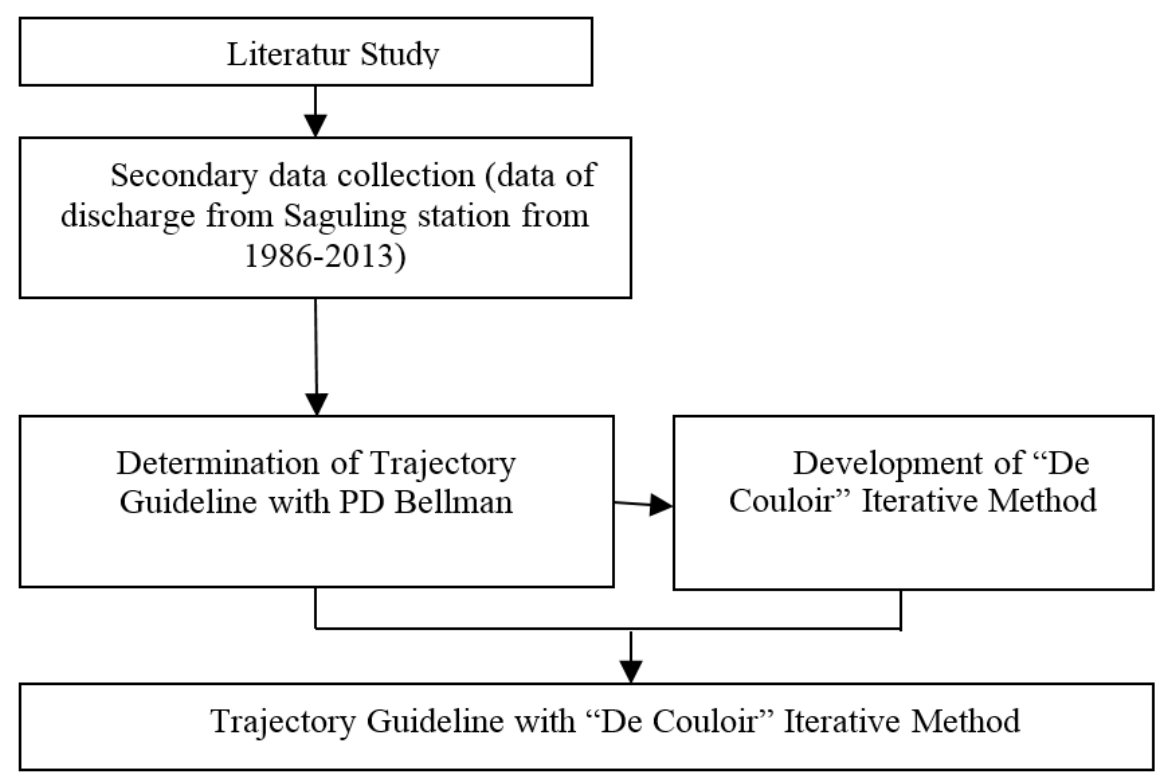

Figure 2. Flowchart of Metodology

The research flow was describe in Figure 2. years that will produce the maximum gain From data inflow of Saguling reservoir, we from production of electricity. "De Couloir" can determine the trajectory guideline for Iterative Method was done to alleviate the Saguling operation in wet, normal, and dry "curse of dimensionality" in PD Bellman. 


\section{Dynamic Programming Bellman (DP Bellman)}

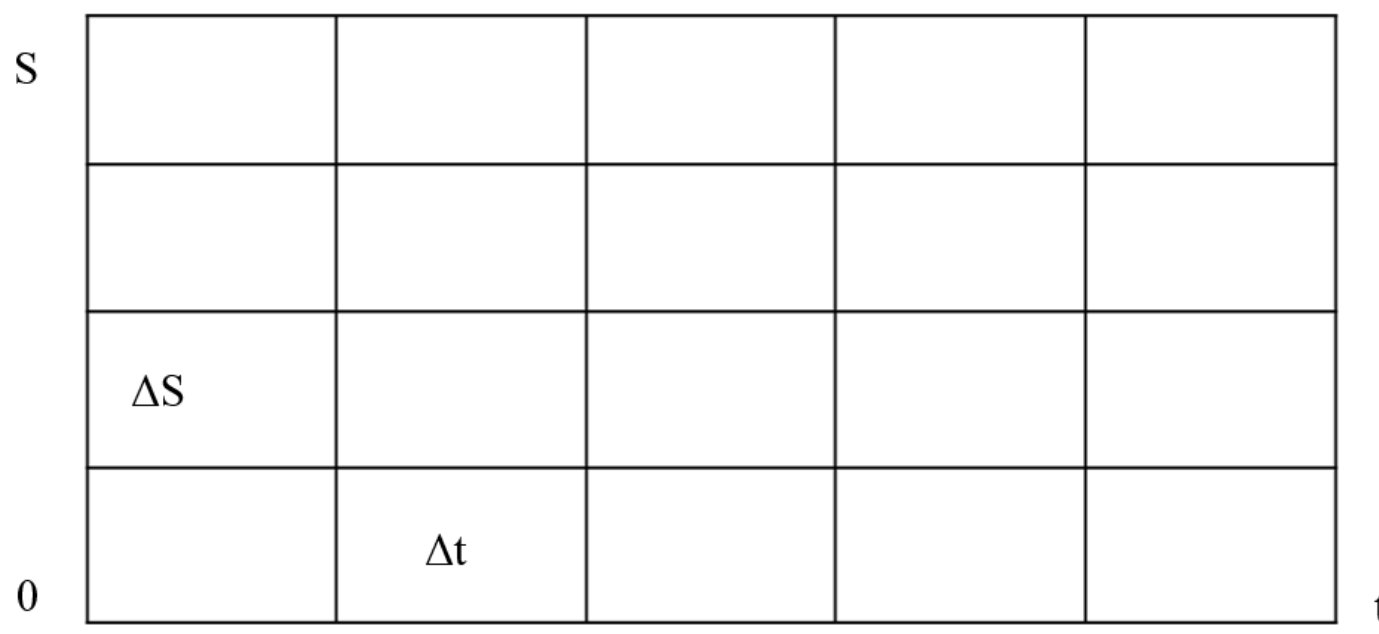

Figure 3. Model of Dynamic

Dynamic programming is a form of problemsolving by providing a variety of optimization techniques where decisions are made sequentially or one stage at a time.

Programming Bellman

$\Delta \Omega=\Omega / m$ and $\Delta t=t / n$

where:

$\mathrm{m}=$ total volume discretization interval

$\mathrm{n}=$ total time discretization interval

$\Omega=$ maximum volume of Saguling Reservoir

$\mathrm{t}=$ operational period

The principle above is the basis to formulate the optimization function limited by several constraints, for instance, to minimize the financing, to maximize the gain, or other purposive functions. Therefore, an optimal state leading to the most suitable decisions in each stage will be acquired.

Dynamic programming Bellman was marked by the presence of time discretization and volume discretization. The establishment of reservoir management model in the format of dynamic programming was carried out as follows:

1. Determine The Time and Volume Discretization

Time discretization assessed in this study was 1 month, 3 months, and 2 weeks. It would identify the number of completion stages of dynamic programming based on the month of a year. Volume discretization of reservoir in this study included 10;25; 50; and 100 million $\mathrm{m}^{3}$, It was adjusted to the expected accuracy.

2. Determine The State and Decision Variable

The state variable was the reservoir volume and the decision variable was the turbine discharge.

3. Determine The 'State-Equation'

In this system, the equation of 'massbalance' of reservoir is the 'state equation'.

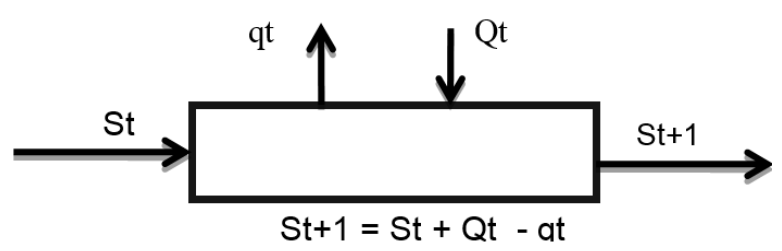

Figure 4. State Equation of Reservoir

4. Determine The Objective Function

The objective function of the operational system of Saguling Reservoir is to maximize the obtained gain from electricity production multiple by its unit price in every month. 
$G=\sum_{1}^{12} P V_{i}\left(t_{i}, S_{i}, T_{i}\right) x N P_{i}$

(1)

where:

$\mathrm{G}=$ gain (unit GWH)

$\mathrm{PV}=$ production valorisess $(\mathrm{GWH})$

$\mathrm{NP}=$ niveau de prix (electricity price)

$G=\sum_{1}^{12} P V_{i}\left(t_{i}, S_{i}, T_{i}\right) x N P_{i}$

$\mathrm{n} \quad=$ turbine efficiency

$=0.916 \times 0.96=0.879$

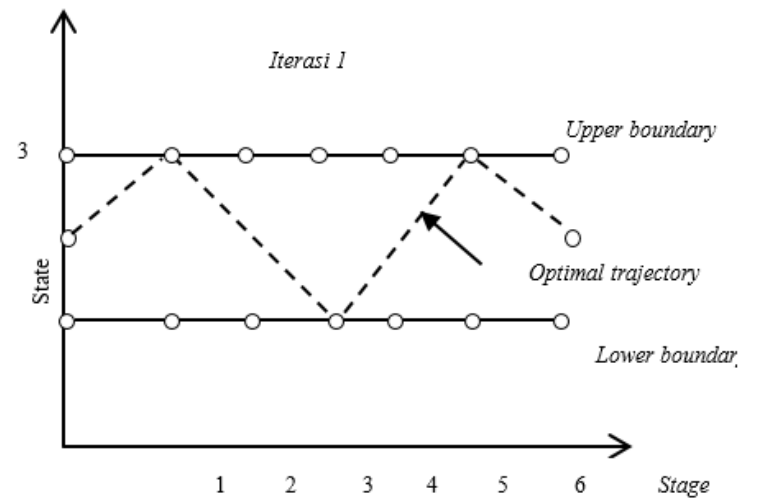

$\mathrm{q}(\mathrm{t})=$ turbine discharge $\left(\right.$ million $\left.\mathrm{m}^{3}\right)$

$\mathrm{H}(\mathrm{t})=$ water pressure height $(\mathrm{m})$

\section{"Du Couloir" Iterative Method}

"Du Couloir" Iterative Method was the development of PD Bellman. Discretization process of " $\mathrm{Du}$ Couloir" iterative method was commenced by rough discretization of $200 \mathrm{~m}^{3}$ in a volume to obtain a trajectory of intermediary reservoir volume towards the stable ideal optimal trajectory processus by forming a channel of reservoir volume trajectory that moves synchronically with the bisection discretization processus.

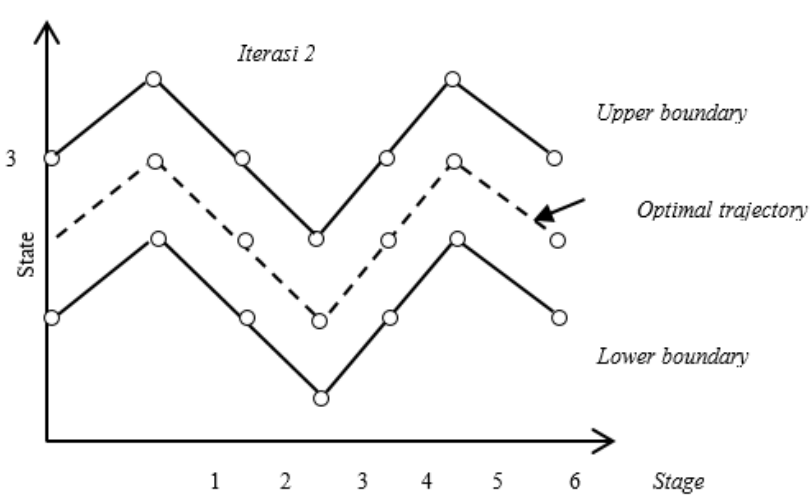

Figure 5. Diagram Concept of "Du Couloir" Iterative Method

Basically, it is explicated that "Du Couloir" iterative method was the determination of a trajectory processus of stable ideal reservoir volume. Discharge used in dynamic

programming study by "Du Couloir" iterative method was the average input discharge of Saguling in wet, normal, and dry years

\section{Result and Discussion}

Combination of Electricity Price in Producing Maximum Gain

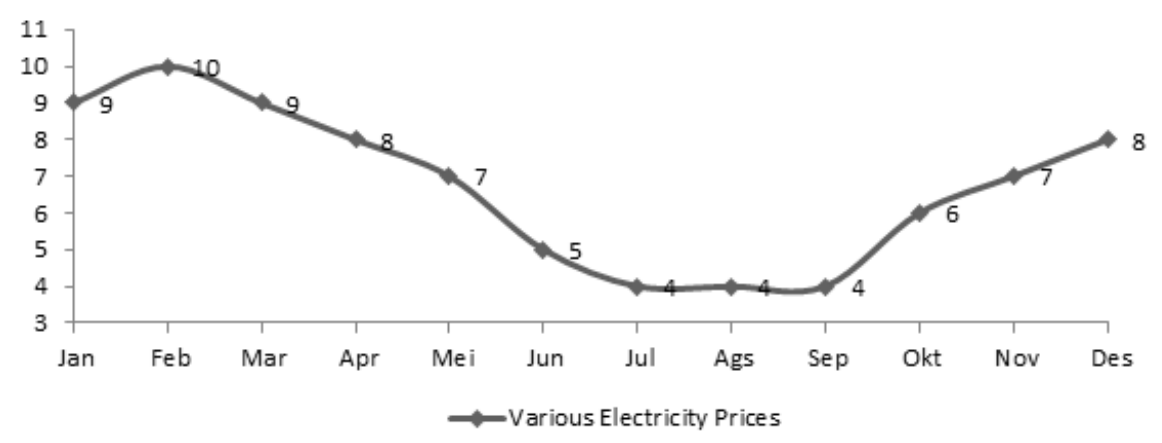

Figure 6. Various Electricity Price (Unit) in Every Month 
DP Bellman was explored to find out the highest gain by analyzing a variety price of electricity production from turbine in each month. Combination of electricity price to determine the trajcetory guideline that will produce a maximum gain was performed from Figure 6.

\section{Effect of Time Discretization to Gain Value}

Reservoir management with DP Bellman was deployed by 2 (two) discretizations, namely time discretization and volume discretization. These selected discretizations would determine the optimum gain derived from the reservoir management system of DP Bellman. Time discretization would specify total phase required in completing DP Bellman.

Time discretization was boldly related to the input discharge of Saguling Reservoir in a period of a year. The lower is the time interval, the lower is the difference of input discharge at every stage of dynamic program. In this study, a variety of time discretization was examined, which were 2 weeks, 1 month, and 3 months.

As demonstrated in Table 1, the less is the time discretization, the higher the gain will be. Nevertheless, the completion time of each stage of dynamic program and computer memory are other considerations in selecting time discretization. In this study, time discretization of 1-month was chosen since 2-week time discretization required a longer completion time as well as a larger computer memory. In addition, 1-month time discretization provided a maximum gain and it was evidenced to be an ideal for reservoir management system.

Table 1. Gain Produced by Each Time Discretization.

Gain Produced with DP Bellman for Each Time Discretization where the Volume Discretization was 10 million m3

\begin{tabular}{cc}
\hline Discretization Time & Gain (unit GWH) \\
3 month & 6622,81 \\
1 month & 20053,36 \\
2 week & 39527,73 \\
\hline
\end{tabular}

\section{Effect of Volume Discretization to Gain Value}

In addition to time discretization, volume discretization also affects the completion time of each stage of reservoir management based on Bellman dynamic program. In this study, a variety of volume discretization was examined including $100 \mathrm{~m}^{3}, 50 \mathrm{~m}^{3}, 25 \mathrm{~m}^{3}$, to 10 million $\mathrm{m}^{3}$. The management system of Saguling Reservoir with those volumes is presented in Figure 7.

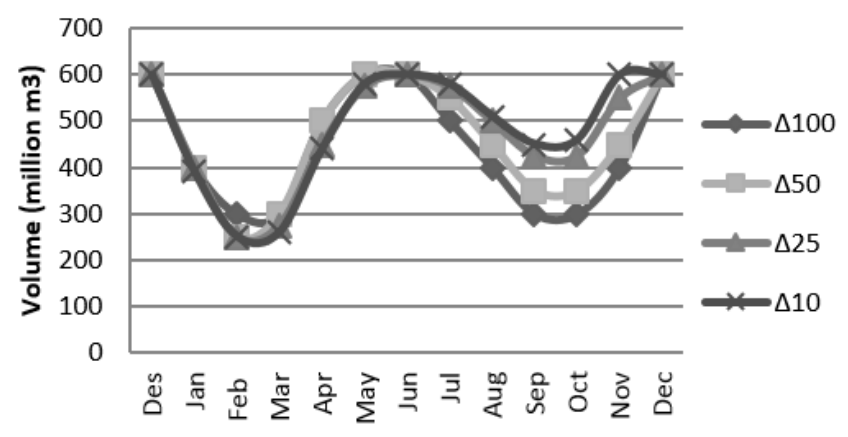

(a)

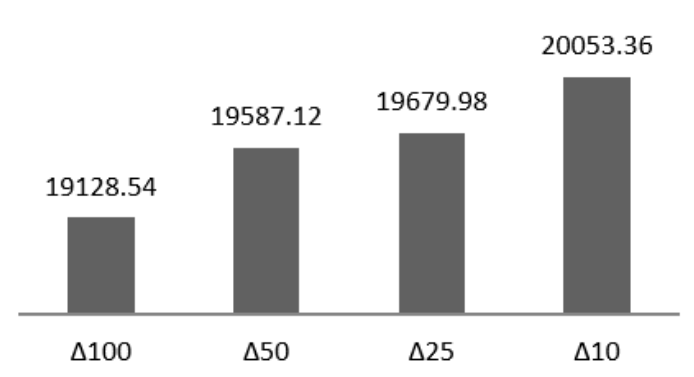

(b)

Figure 7. (a) Management system of Saguling Reservoir with diverse volume discretizations, and (b) The gain of each volume discretization.

It can be identified from Figure 6 that the lower was the volume discretization; the higher was the obtained gain. It also indicates that the highest gain of operational Saguling was attained by smaller volume discretization with DP Bellman which was 10 million $\mathrm{m}^{3}$. 
Determination of Trajectory Guideline in Saguling Reservoir by Analyzing the Wet, Normal, and Dry Discharge

Volume discretization and time discretization producing the maximum gain had been determined, subsequently, the completion of dynamic program with the conditions of wet, normal, dry years was carried out. The detail illustration of the completion is presented in Figure 8 and the gain of electricity production that produced for every condition was presented in Table 2.

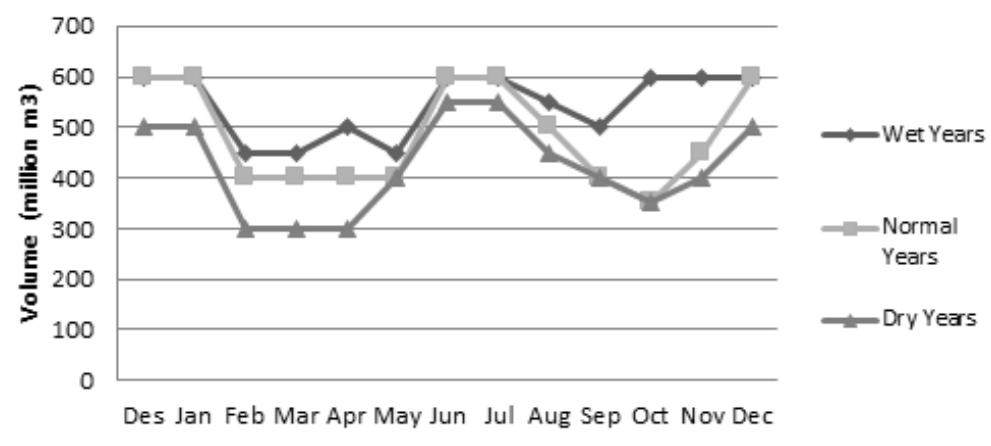

Figure 8. Trajectory Guideline of Saguling in Wet, Normal, and Dry years with DP Bellman

Table 2. Gain of Each Trajectory Guideline in Wet, Normal, and Dry years

\begin{tabular}{lc}
\hline \multicolumn{2}{c}{ Gain Produced (unit GWH) } \\
\hline Wet Years & 26359 \\
Normal Years & 22319 \\
Dry Years & 16801 \\
\hline
\end{tabular}

Figure 8 and Table 2 showed the maximum gain generated by, respectively, the wet, normal, and dry years. The turbine's maximum performance in the wet years is the main reason of the optimum gain.
Trajectory Guideline with "Du Couloir" Iterative Method

Benefit from "Du Couloir" Iterative Method usage in this research that we can obtain the trajectory guideline with smaller discretization volume until 0,1 million $\mathrm{m}^{3}$ so that maximum profit can be achieved along with computional efficiency. Trajectory guideline with "Du Couloir" Iterative Method of each wet, normal, and dry years condition was presented in Figure 9 until Figure 11.

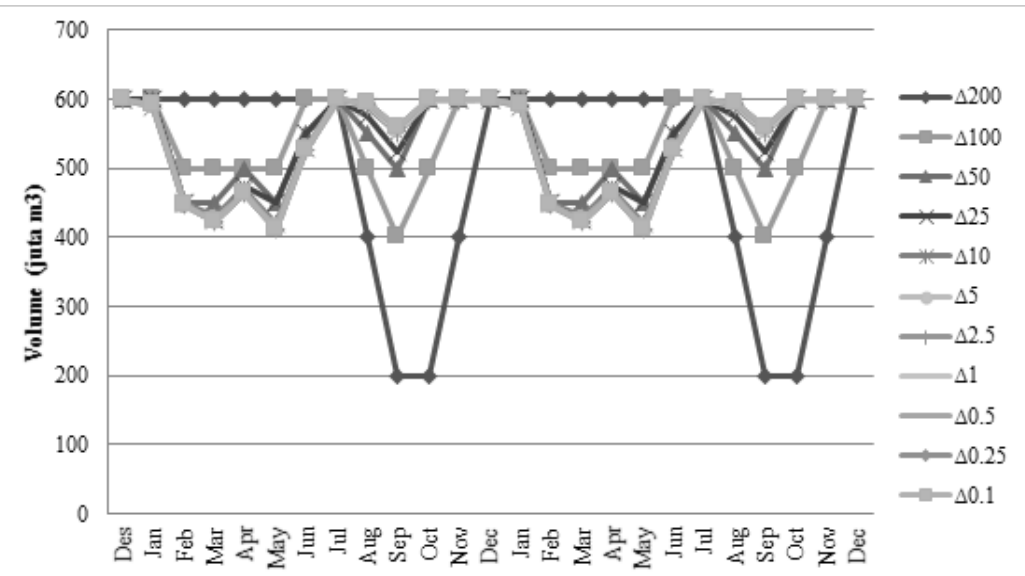

Figure 9. Trajectory Guideline of Saguling in Wet Years with "Du Couloir" Iterative Method 


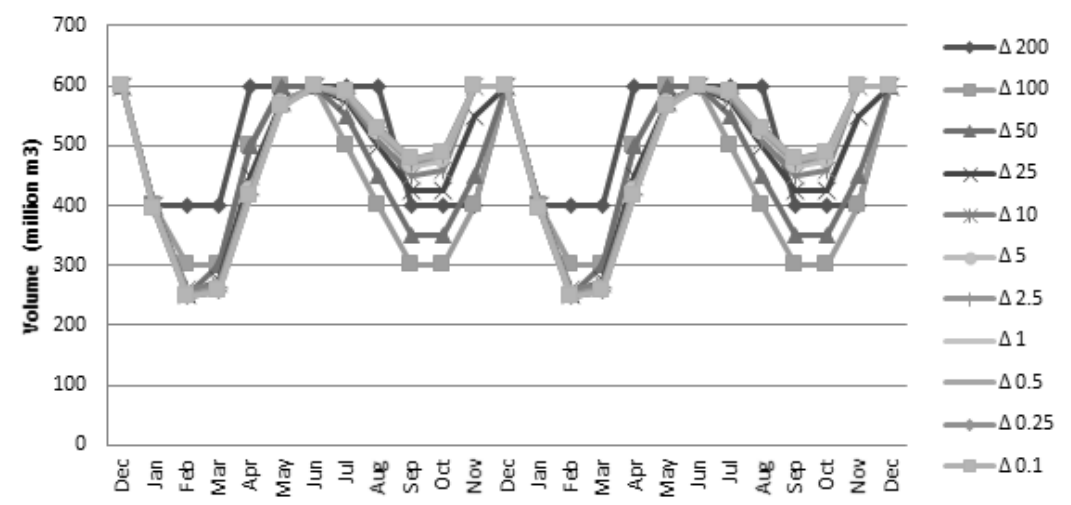

Figure 10. Trajectory Guideline of Saguling in Normal Years with "Du Couloir" Iterative Method

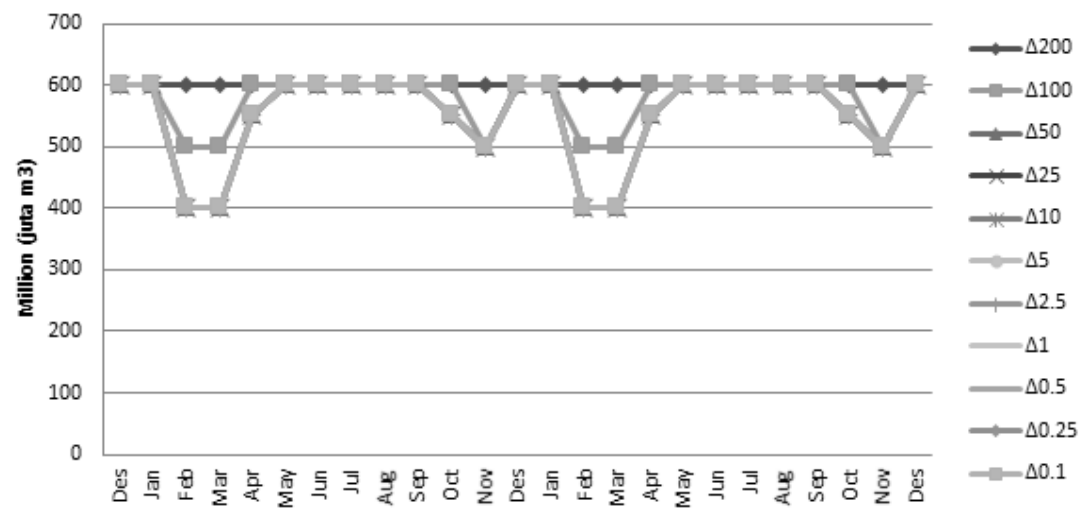

Figure 11. Trajectory Guideline of Saguling in Dry years with "Du Couloir" Iterative Method

Determination of trajectory guideline normal, and dry discharge that was done by and gain produced with 0,1 million $\mathrm{m} 3$ "Du Couloir" Iterative Method is presented in discretization volume by analyzing the wet, Figure 12 .

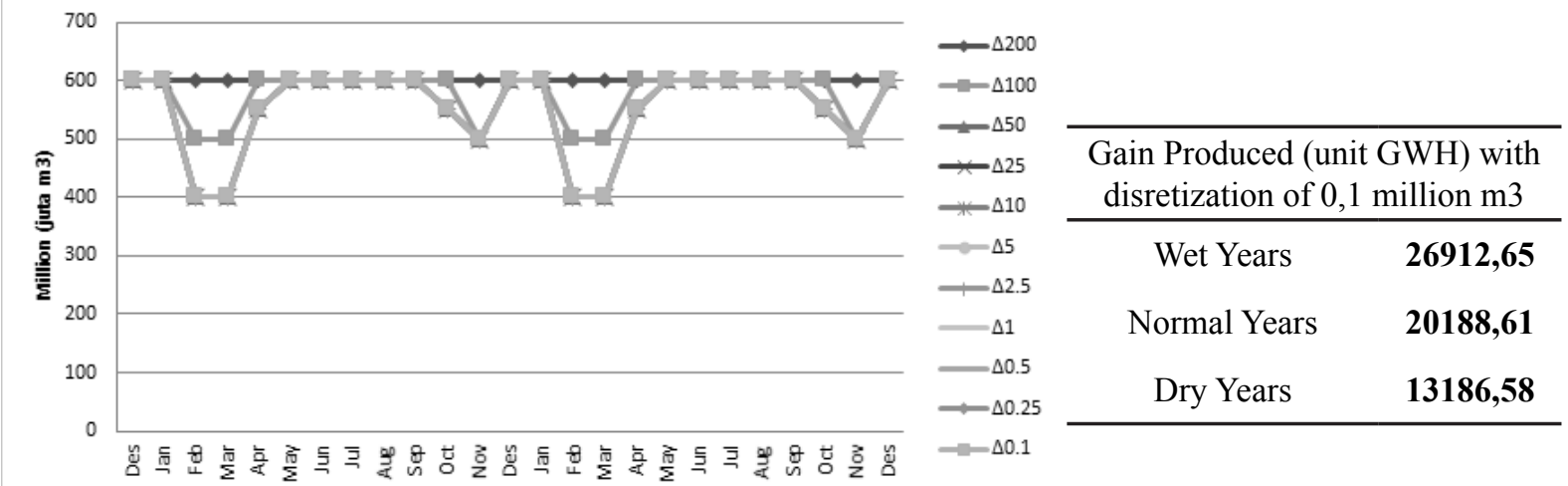

Figure 12. Trajectory Guideline and Gain Produced of Saguling in Wet, Normal, and Dry years with "Du Couloir" Iterative Method

Comparison of Optimization Model of to conventional DP Bellman method. Bellman and Cross-Dynamic Iterative "Du Couloir" iterative method was able Method to complete the problem of dynamic Figure13 below demonstrated the programming 50 times faster than efficiency of calculated time by using the method of conventional dynamic "Du Couloir" iterative method compared programming. 


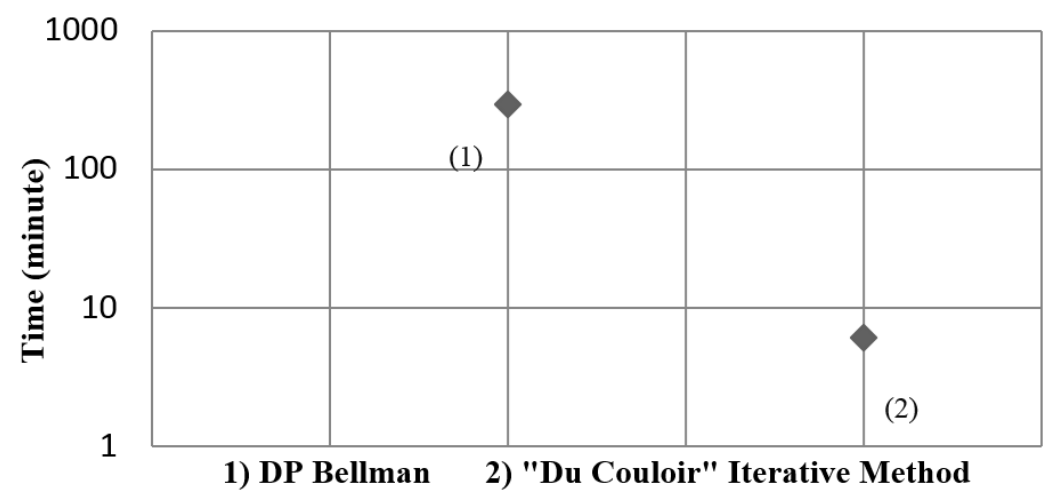

Figure 13. The Comparison of Completion Time between Bellman Method and "Du Couloir" Iterative Method

\section{Conclusion}

Discretization time and discretization volume was influenced the gain produced from reservoir operation. Smaller discretization time and value that been used, then higher gain value that will produced. This research showed that "Du Couloir" iterative method was capable to solve the discretization problems faster than the conventional DP Bellman. "Du Couloir" iterative method can reach discretization volume until 0,1 million $\mathrm{m} 3$ with efficient computational time. Trajectory guideline in this reserach was conducted for wet, normal, and dry years condition. Gain produced of 0,1 million $\mathrm{m} 3$ with "Du Couloir" iterative method in wet years was 26912,65 unit GWH, in normal years was 20188,61 unit GWH, and in dry years was 13186,58 unit GWH. Determinaton of trajectory guideline of Saguling reservoir with smaller discretization volume was important because it can give maximum benefit from electricity production and the trajectory guideline will be closer to trajectory actual so optimization of Saguling operation will be achieved.

\section{References}

Arwin. 1992. Modelisation des Resources en Eau et Leur Exploitation Energetique sur L'exemple du Bassin Superieur du Citarum en Indonesie. Dissertation, INPT Toulouse, France.

Thirrot., Arwin. 1991. Detailed Critical Numerical Study of Discretizing Effects in Optimizing Using Bellman's Dynamic Programming. Method Computer Aided Engineering in Water Resources. 3:67-81.

Fayaed, Sabah S. 2013. Reservoir-System Simulation and Optimization Techniques. Stoch Environ Res Risk Assess, 27:1751-1772.

Heidari M, Chow VT, Kokotovic PV, Meredith DD. 1971. Discrete differential Dynamic Programming Approach to Water Resources Systems Optimization. Water Resour Res.7(2):273-82

Larson RE. 1968. State increment dynamic programming. New York: Elsevier Science.

Larson RE, Korsak AJ. 1970. Dynamic Programming Successive Approximations Technique with Convergence Proofs. Automatica. 6(2):245-52.

Muchlis. 2003. Analisis Kebutuhan Listrik di Indonesia 2003-2020. Perusahaan Listrik Negara Indonesia.

Santosa, P. B., Mitani, Y.. 2009. Geospatial Analysis And Turbidity Measurement For Monitoring Suspended Solid Of Hitotsuse Dam In Miyazaki Prefecture, Kyushu, Japan. Forum Geografi. 29(2), pp: 153 - 164. 
Forum Geografi, Vol 30 (1) July 2016: 14-23

Management Optomozation of...(Marselina et al.)

Trott WJ, Yeh WWG. 1973. Optimization of Multiple Reservoir System. J Hydraul Eng Div;99(10):1865-84. 